\title{
Shotgun metagenomic sequencing from Manao-Pee cave, Thailand, reveals insight into the microbial community structure and its metabolic potential
}

Apirak Wiseschart', Wuttichai Mhuantong ${ }^{2}$, Sithichoke Tangphatsornruang ${ }^{2}$, Duriya Chantasingh ${ }^{2}$ and Kusol Pootanakit ${ }^{1 *}$ (iD

\begin{abstract}
Background: Due to the cave oligotrophic environment, this habitat presents a challenge for microorganisms to colonize and thrive. However, it has been well documented that microorganisms play important roles in cave development. Survival of microbes in this unique habitat likely involves a broad range of adaptive capabilities. Recently, cave microbiomes all over the world are of great scientific interest. However, the majority of investigations focused mostly on small subunit ribosomal RNA (16S rRNA) gene, leaving the ecological role of the microbial community largely unknown. Here, we are particularly interested in exploring the taxonomic composition and metabolic potential of microorganisms in soil from Manao-Pee cave, a subterranean limestone cave in the western part of Thailand, by using high-throughput shotgun metagenomic sequencing.

Results: From taxonomic composition analysis using ribosomal RNA genes (rRNA), the results confirmed that Actinobacteria (51.2\%) and Gammaproteobacteria (24.4\%) were the dominant bacterial groups in the cave soil community. Metabolic potential analysis, based on six functional modules of the Kyoto Encyclopedia of Genes and Genomes (KEGG) database, revealed that functional genes involved in microbial metabolisms are highly represented in this community (40.6\%). To better understand how microbes thrive under unfavorable cave condition, we focused on microbial energy metabolism. The results showed that microbial genes involved in oxidative phosphorylation were the most dominant (28.8\%) in Manao-Pee cave, and were followed by methane metabolism (20.5\%), carbon fixation (16.0\%), nitrogen metabolism (14.7\%), and sulfur metabolism (6.3\%). In addition, microbial genes involved in xenobiotic biodegradation (26 pathways) and in production of secondary metabolites (27 pathways) were also identified.

Conclusion: In addition to providing information on microbial diversity, we also gained insights into microbial adaptations and survival strategies under cave conditions. Based on rRNA genes, the results revealed that bacteria belonging to the Actinobacteria and Gammaproteobacteria were the most abundant in this community. From metabolic potential analysis, energy and nutrient sources that sustain diverse microbial population in this community might be atmospheric gases (methane, carbon dioxide, nitrogen), inorganic sulfur, and xenobiotic compounds. In addition, the presence of biosynthetic pathways of secondary metabolites suggested that they might play important ecological roles in the cave microbiome.
\end{abstract}

Keywords: Manao-Pee cave, Culture-independent approach, Shotgun metagenomic sequencing, Metabolic potential analysis, KEGG pathways

\footnotetext{
* Correspondence: kusol.poo@mahidol.ac.th

${ }^{1}$ Institute of Molecular Biosciences, Mahidol University, Salaya Campus,

Phuttamonthon 4 Rd, Salaya, Nakhon Pathom 73170, Thailand

Full list of author information is available at the end of the article
}

(c) The Author(s). 2019 Open Access This article is distributed under the terms of the Creative Commons Attribution 4.0 International License (http://creativecommons.org/licenses/by/4.0/), which permits unrestricted use, distribution, and reproduction in any medium, provided you give appropriate credit to the original author(s) and the source, provide a link to the Creative Commons license, and indicate if changes were made. The Creative Commons Public Domain Dedication waiver (http://creativecommons.org/publicdomain/zero/1.0/) applies to the data made available in this article, unless otherwise stated. 


\section{Background}

Recent high-throughput sequencing technologies are robust and economical for microbial ecology study. 16S rRNA gene is usually directly amplified from extracted metagenomic DNA of environmental samples for the exploration of prokaryotic diversity [1, 2]. However, it is well-known that PCR-based studies have several limitations [3]. For instance, variability in PCR amplification efficiency, chimera formation (hybrid products between multiple parent sequences), and potential PCR primers bias $[1,4,5]$. As high-throughput sequencing technologies typically generate short reads, only a single or a combination of neighbouring hypervariable regions of 16S rRNA gene are normally used in microbial diversity analysis. It is worth noting that different genes as well as different regions of the same gene usually have different accuracy and coverage for their operational taxonomic unit (OTU) abundance estimation [6-8]. Primer selection is thus very important in a PCR-based microbial ecology study. In addition, as this technique gives only the relative abundance information, the ecological roles of microbial communities thus largely remained unknown $[8,9]$.

As one of the main objectives in the study of microbial ecology is to establish a relationship between taxonomic distribution, i.e. who are there, and their ecological functions, i.e. what are they capable of doing, of complex microbial communities [10]. Thus, in the last few years, several bioinformatic approaches have been used to predict metabolic potential of the microbial community using information based solely on the obtained $16 \mathrm{~S}$ rRNA gene sequences [11-13]. As this prediction is always based on the marker gene amplification, the accuracy of such an approach is also dependent on how reliable is the PCR technique employed. In addition, availability of nutrients and chemicals in ecological niches also influence metabolic activity of microorganisms [14]; consequently, their ecological activities are very complex to predict. Last but not least, functional prediction based on what we know about closely related species is not always true as even those closely related microorganisms frequently have different important functional genes [15]. Therefore, it would be better to gain a deeper insight into community's functional capabilities from unamplified environmental DNA (eDNA).

Shotgun metagenomic DNA sequencing does not rely on PCR amplification using gene-targeted primers; thus, it is a powerful technique in the field of molecular microbial ecology [8]. Because of the technical differences, amplicon sequencing and metagenomic shotgun sequencing may not give identical results. However, it has been reported that metagenomic shotgun sequencing provides a more robust and reliable assessment of the microbial diversity [3, 16]. Additionally, it not only provides a direct assessment of the microbial profile but also gives valuable information on metabolic potential of the microbial community $[3,8,17]$. However, one of the drawbacks to this approach is the incomplete gene annotations as only limited numbers of bacterial genomes are available [6]. Also, when compared to amplicon sequencing, the cost of shotgun sequencing is more expensive and requires more extensive data analysis [3, $8,16]$. Even with these limitations, it is still a promising molecular technique to close the gap between community structure and functional capability, contributing to a better understanding of how microbes thrive and adapt under natural conditions especially in less explored habitats. Here, we used Ion Torrent PGM to obtain the eDNA reads. Eventhough this platform gives higher indel errors especially in the homopolymer regions when compared to others [18], it nevertheless achieved comparable results when compared to the Illumina MiSeq datasets for functional categorization of assembled shotgun sequences [19].

Cave microbiomes are one of the least studied biomes [20]. This may be because of restrictions to avoid damage to natural resources, or that cave sampling is not as easy when compared to surface habitats. In the cave ecosystem, beyond the twilight zone, photosynthesis does not occur. Consequently, oligotrophic conditions are always found deep inside the caves. Even with this nutrient-limited condition, they are by no means barren or lifeless. A wide spectrum of microorganisms can thrive in the cave environment [21]. It has been reported that microorganisms play important ecological roles in cave development via direct or indirect activities [22, 23]. Recently, microbial diversity has been investigated in caves around the world. Based on 16S rRNA gene sequencing, mounting evidence indicates that Actinobacteria and Proteobacteria are the most ubiquitous bacteria phyla in cave ecosystems [21, 24]. As opposed to microbial profiling data, information on metabolic potential of the cave microbiome is very limited. To the best of our knowledge, only a few studies have shown metabolic capabilities of cave microorganisms. For instance, results from the metabolic potential analysis of microorganisms on carbonate speleothem surfaces of Kartchner Caverns, USA, revealed that the prokaryotic community genetically adapted to low-nutrient conditions by using alternative nonphotosynthetic primary production strategies (e.g. $\mathrm{CO}_{2}$ fixation, nitrogen metabolism) [25]. Yet another study investigated microbial communities embedded in a secondary mineral deposit from Tjuv-Ante's cave identified microbial genes related to iron and sulfur metabolisms [26].

However, to date no such study has been conducted on cave soil sediments. Analysis of microbial metabolic potential of this community might provide opportunities 
to expand our understanding about survival strategies of cave microorganisms. Therefore, the present study aimed to explore microbial community structure and also metabolic potential of the soil community from a subterranean limestone cave of Khao Wang Khamen. As far as we know, this study is the first shotgun metagenomic sequencing of cave microbiome in Thailand. The work presented fills a much needed knowledge gap regarding microbial community structure and on how cave-dwelling microbes thrive under energetically unfavorable and nutrient-limited conditions.

\section{Methods}

\section{Site description and sampling}

Manao-Pee cave is part of the extensive Khao Wang Khamen karst system. It is located in Kanchanaburi province, in the western part of Thailand. The cave is off-limit to tourists and the public as it is under the protection of The Royal Thai Armed Forces Development Command. Within the cave, a wide diversity of white to brown-orange calcite speleothems (secondary mineral deposits) are present. In the current study, we are particularly interested in the cave soil since we wanted to know how microorganisms survive under nutrientlimited cave condition. When compared to the soil outside the cave, the cave soil is more brownish and sandy. In terms of geochemical composition, our previous study has shown that copper $(\mathrm{Cu})$, iron $(\mathrm{Fe})$, manganese $(\mathrm{Mn})$, and zinc $(\mathrm{Zn})$ were found at higher concentrations in soil samples from the cave [27]. Conversely, organic matter, total carbon, total nitrogen, and total hydrogen were found to be at lower concentrations when compared to soil samples outside the cave. For the present study, soil samples were collected from 5 different locations inside the dark zone of the cave, about $20-50 \mathrm{~m}$ from the cave entrance. All soil samples were kept on ice before returning to the laboratory and immediately stored at $-20^{\circ} \mathrm{C}$ until processed.

\section{Total environmental DNA extraction and purification}

Total environmental DNA (eDNA) was directly extracted from a composite soil sample as described previously [27]. Specifically, $5 \mathrm{~g}$ of composite soil was mixed with $13.5 \mathrm{ml}$ of DNA extraction buffer $(100 \mathrm{mM}$ Tris$\mathrm{HCl}$ (pH 8.0), $100 \mathrm{mM}$ sodium EDTA (pH 8.0), $100 \mathrm{mM}$ sodium phosphate ( $\mathrm{pH} 8.0), 1.5 \mathrm{M} \mathrm{NaCl}, 1 \%(\mathrm{w} / \mathrm{v})$ cetyltrimethylammonium bromide (CTAB)) and $100 \mu \mathrm{l}$ of proteinase $\mathrm{K}(10 \mathrm{mg} / \mathrm{ml})$. The mixture was vigorously shaken at $250 \mathrm{rpm}, 37^{\circ} \mathrm{C}$ for $30 \mathrm{~min}$. Then, $1.5 \mathrm{ml}$ of $20 \%(\mathrm{w} / \mathrm{v})$ SDS was added to the mixture. It was further incubated at $65^{\circ} \mathrm{C}$ for $2 \mathrm{~h}$. During this time, the mixture was gently mixed every $15-20 \mathrm{~min}$. After $2 \mathrm{~h}$, the mixture was centrifuged at $6000 \times \mathrm{g}$ for $10 \mathrm{~min}$ at room temperature. The supernatant was transferred to new 50 $\mathrm{ml}$ centrifuge tube, the soil pellet was re-extracted by adding $4.5 \mathrm{ml}$ of DNA extraction buffer and $0.5 \mathrm{ml}$ of $20 \%(w / v)$ SDS. It was further incubated at $65^{\circ} \mathrm{C}$ for 15 min. After that, the supernatant was collected as described above. All supernatants were then combined and mixed with equal volume of chloroform: isoamylalcohol $(24: 1(\mathrm{v} / \mathrm{v}))$. The upper phase was collected to new tube after centrifugation at $6000 \times g$ for $10 \mathrm{~min}$ at $4{ }^{\circ} \mathrm{C}$. eDNA was precipitated with 0.7 volumes of isopropanol and incubated for $1 \mathrm{~h}$ at room temperature. The precipitated eDNA was pelleted by centrifugation at $16,000 \times g$ for 20 min at $4{ }^{\circ} \mathrm{C} .300 \mu \mathrm{l}$ of ice-cold $70 \%$ ethanol (v/v) was added to the DNA pellet and centrifuged again at 16, $000 \times g$ for $10 \mathrm{~min}$ at $4{ }^{\circ} \mathrm{C}$. Then, eDNA pellet was airdried at room temperature and resuspended in $100 \mu \mathrm{l}$ of sterilized MiliQ water. Finally, the extracted eDNA was purified by using electroelution technique.

\section{Purification of environmental DNA by electroelution technique}

Extracted eDNA was purified by electroelution technique [28], with slight modifications. Specifically, crude eDNA was separated through $1 \%$ agarose gel in 0.5X TBE buffer with constant voltage of $100 \mathrm{v}$. After $1 \mathrm{~h}$, any remaining DNA that did not migrate into the agarose gel was washed out of the loading wells, and the buffer was replaced. The voltage was then reduced to $20 \mathrm{v}$, and the gel was run for $5 \mathrm{~h}$. Then, a slice of agarose gel containing high molecular weight eDNA was then cut out with a sharp scalpel. The excised gel was then put into a dialysis bag (Spectra/Por, USA) filled with $0.25 \mathrm{x}$ TBE buffer. Next, the bag was immersed in a shallow layer of $0.25 \mathrm{x}$ TBE buffer in a horizontal electrophoresis tank in an orientation that was inline with the electrodes, with the current at $100 \mathrm{v}$ for $90 \mathrm{~min}$. The polarity of electric current was then reversed for $1 \mathrm{~min}$ to release any eDNA sticking to the wall of dialysis bag. The buffer with eluted eDNA was transferred into a $15 \mathrm{ml}$ tube. One volume of chloroform:isoamylalcohol $(24: 1(\mathrm{v} / \mathrm{v}))$ was added and mixed before centrifugation at $6000 \times g$ for $10 \mathrm{~min}$. The upper phase was transferred to a clean $15 \mathrm{ml}$ tube. Eluted eDNA was then precipitated by adding $1 / 10$ volume of $3 \mathrm{M}$ sodium acetate ( $\mathrm{pH} 5.2$ ) and 0.7 volume of isopropanol. After $1 \mathrm{~h}$ of incubation at room temperature, eluted eDNA was pelleted by centrifugation at $13,000 \times g$ for $20 \mathrm{~min}$. After washing with $70 \%$ ethanol $(\mathrm{v} / \mathrm{v})$, eDNA pellet was air-dried at room temperature and resuspended in $50 \mu \mathrm{l}$ of sterilized MiliQ water.

\section{Shotgun metagenomic sequencing and metabolic potential analysis}

Purified eDNA was sequenced using Ion Proton sequencing system (Life Technologies, USA) following the manufacturer's protocol. The metagenomic sequence 
reads obtained are available at the NCBI Sequence Read Archive (https://www.ncbi.nlm.nih.gov/sra) with the accession number PRJNA485054. The quality of sequencing datasets were initially assessed using FastQC software [29]. Sequences with low Phred quality score $(<20)$ and shorter than 100 base pairs in length were filtered out. The remaining sequences were translated into amino acid sequences for their protein-coding regions through the MetaGeneMark program [30]. The functional annotation of metagenomic sequences was performed by the Reduced Alphabet based Protein similarity Search tool (RAPSEARCH2) [31] against the UniRef90 database [32]. The similarity search output from RAPSEARH was subsequently assigned for functional annotation using KEGG classification through Metagenome Analyzer (MEGAN) tool (version 6) [33]. Meanwhile, the remaining non-protein coding sequences were identified for rRNA sequences using BLASTN against the SILVA database [34]. All BLAST searches for rRNA genes were performed using the expected cutoff value of $1 \mathrm{e}^{-6}$.

\section{Results}

\section{Shotgun sequencing dataset}

Purified eDNA was subjected to high-throughput Ion Proton sequencing. Approximately 19 million sequences with an average read length of $184 \mathrm{bp}$ were obtained. After quality control, 17,353,239 (87.9\%) sequence reads were suitable for further bioinformatic analysis. This number included both coding and non-coding sequences. Specifically, a total reads of 4,556,991 (26.3\%) were of non-coding sequences. From this dataset, 46,567 reads contained rRNA genes $(1.0 \%)$ that can be taxonomically assigned to cellular organisms. For coding sequences, a total reads of 12,796,248 (73.7\%) was subjected to KEGG analysis for Manao-Pee's metabolic potential.

\section{Microbial community structure in the Manao-Pee cave soil community through $16 \mathrm{~S}$ rRNA gene}

As expected most of the 46,567 rRNA genes identified can be phylogenetically assigned to the bacteria domain (96.6\%). Only a small fraction were assigned to the archaeal (2.6\%) and eukaryotic domains (0.8\%) (Fig. 1).

Actinobacteria (51.2\%) and Proteobacteria (32.9\%) were the most abundant phyla in the cave soil community. Other bacterial phyla were also identified, but they were much less abundant, namely, Bacteroidetes (3.9\%), Fimicutes (3.7\%), Acidobacteria (1.8\%), Planctomycetes (1.6\%), Chloroflexi (1.1\%), Gemmatimonadetes (0.6\%), and Cyanobacteria (0.5\%) (Fig. 2).

Among the Actinobacteria, 36 families were identified. The most abundant was Pseudonocardiaceae (21.1\%), followed by Nocardioidaceae (17.8\%), Streptomycetaceae (11.5\%), Mycobacteriaceae (14.3\%), Micromonosporaceae

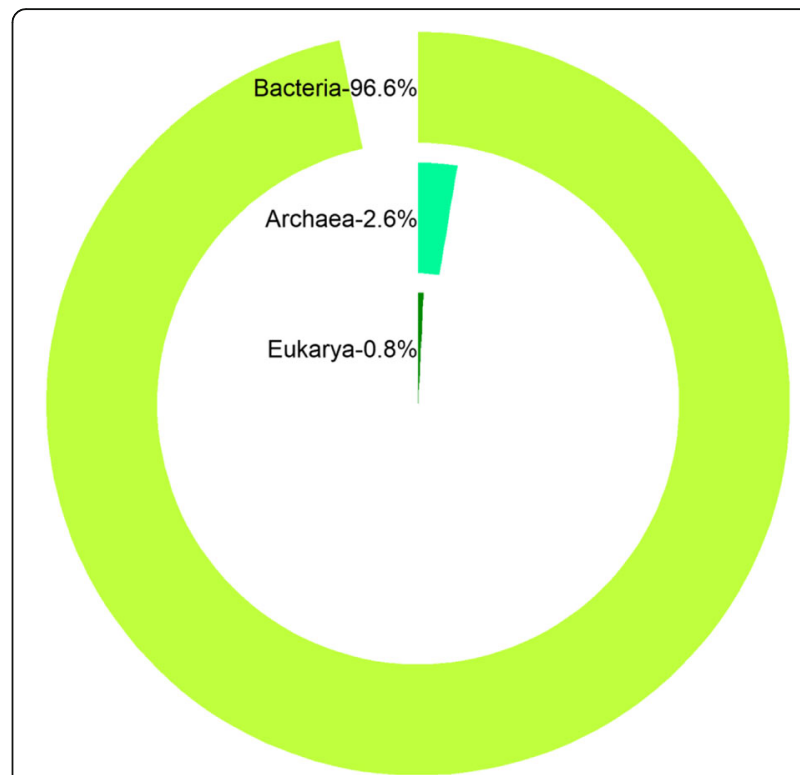

Fig. 1 Distribution of organisms in soil community from the ManaoPee cave. Percentage values represent the relative abundance of non-coding genes assigned to a particular domain

(8.2\%), Nocardiaceae (5.0\%), Thermomonosporaceae (3.3\%), Frankiaceae (2.3\%), Propionibacteriaceae (1.9\%), Glycomycetaceae (1.4\%), Sporichthyaceae (1.2\%), Intrasporangiaceae (1.2\%), and Microbacteriaceae (1.1\%). The remaining 23 families have less than $1 \%$ (Additional file 1: Figure S1a). At the genus level, 117 genera were identified. Mycobacterium (15.1\%) was the most abundant genus, followed by Streptomyces (11.9\%), Nocardioides (9.4\%), Marmoricola (4.7\%), Crossiella (4.1\%), Amycolatopsis (4.0\%), Nocardia (3.1\%), Pseudonocardia (2.8\%), Saccharopolyspora (2.7\%), Actinoplanes (2.1\%), Frankia (2\%), Spirillospora (1.8\%), Aeromicrobium (1.8\%), Micromonospora (1.5\%), Rhodococcus (1.4\%), Salinispora (1.4\%), Saccharomonospora (1.3\%), Sporichthya (1.2\%), Saccharothrix (1.1\%), Stackebrandtia (1.1\%) and Mumia (1.0\%). The remaining genera accounted for less than $1 \%$ (Additional file 1: Figure S1b).

Proteobacteria was the second most prevalent phylum in this community. Most of these sequences can be classified into the class Gammaproteobacteria (77.4\%), followed by Betaproteobacteria (10.2\%), Alphaproteobacteria (8.6\%), Deltaproteobacteria (3.5\%), and Epsilonproteobacteria (0.3\%) (Additional file 2: Figure S2a). Amoung the 81 families identified, Xanthomonadaceae (43.9\%) was the most abundant in this community, followed by Burkholderiaceae (7.9\%), Ectothiorhodospiraceae (6.9\%), Salinisphaeraceae (5.0\%), Enterobacteriaceae (4.1\%), Chromatiaceae (3.7\%), Pseudomonadaceae (3.2\%), Sphingomonadaceae (1.7\%), Rhodospirillaceae (1.6\%), Methylococcaceae (1.6\%), Coxiellaceae (1.5\%), Halomonadaceae (1.3\%), Rhodobacteraceae (1.2\%), 


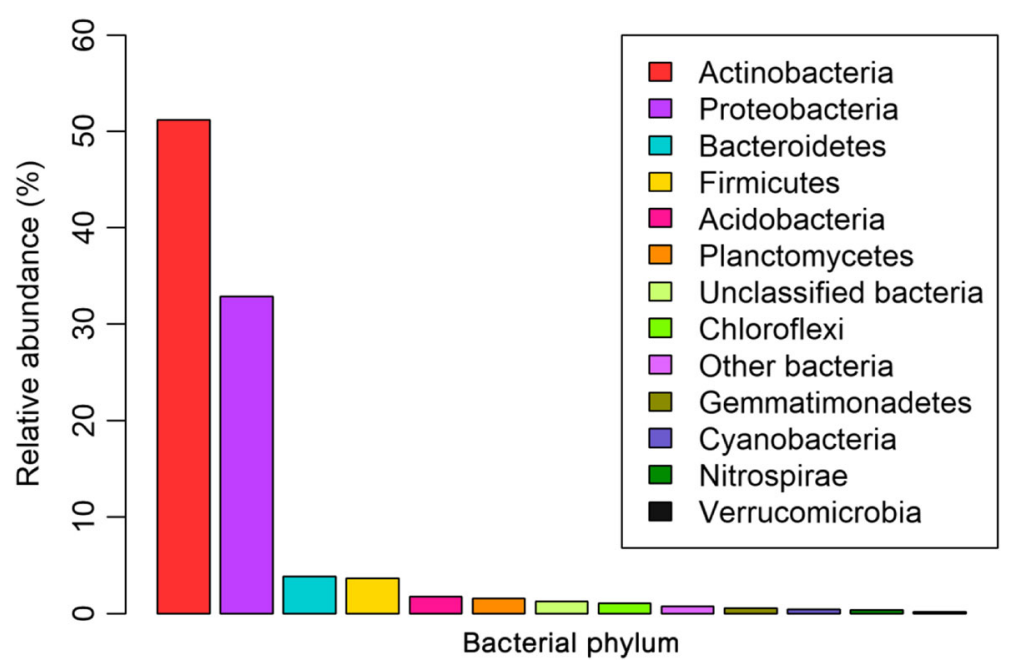

Fig. 2 Bacterial diversity in soil community from the Manao-Pee cave. Percentage values represent the relative abundance of non-coding genes assigned to a particular phylum

Piscirickettsiaceae (1.1\%), and Moraxellaceae (1.0\%). The other families accounted for less than 1\% (Additional file 2: Figure S2b). Among 171 genera identified, Burkholderia (11.9\%) was the most abundant genus in this community, followed by Salinisphaera (6.6\%), Lysobacter (6.1\%), Xanthomonas (5.5\%), Thioalkalivibrio (5.1\%), Arenimonas (3.9\%), Pseudomonas (3.8\%), Pseudoxanthomonas (2.9\%), Coxiella (2.5\%), Sphingomonas (2.2\%), Spiribacter (2.0\%), Nitrococcus (1.8\%), Thermomonas (1.4\%), Rhizobium (1.3\%), Cycloclasticus (1.1\%), Nitrosococcus (1.1\%), Methylobacter (1.1\%), Halomonas (1.1\%), Ectothiorhodospira (1.0\%), and Salmonella (1.0\%). The remaining genera accounted for less than 1\% (Additional file 2: Figure S2c).

Thaumarchaeota (90.7\%) occupied the largest proportion in the archaeal domain. However, all reads assigned to this phylum could not be classified into deeper taxonomic level. Euryarchaeota (8.9\%) was the second most dominant phylum, followed by Crenarchaeota (0.4\%) (Additional file 3: Figure S3).

Among the eukaryotic organisms, the kingdom fungi (82.9\%) was the most prevalent in this community with the division Ascomycota contributing 62.6\%, followed by Basidiomycota (16.0\%), Mucoromycota (2.4\%), and Zoopagomycota (1.9\%) (Additional file 4: Figure S4).

\section{Metabolic potential analysis of cave-dwelling microorganisms}

Metabolic potential analysis was performed by mapping reads to the Kyoto Encyclopedia of Genes and Genomes (KEGG) database based on six functional modules (metabolism, genetic information processing, environmental information processing, cellular processes, organismal systems, and human diseases). The results indicated that metabolism-related genes were the most represented in this community, accounting for $40.6 \%$ of the dataset (Fig. 3), followed by genes that are involved in genetic information processing (11.9\%) (e.g. transcription, translation, replication and repair), environmental information processing (7.4\%) (membrane transport, signal transduction, and signaling molecules and interaction), cellular processes (2.1\%) (e.g. transport and catabolism, cell motility, cell growth and death), organismal systems (1.1\%) (e.g. environmental adaptation, immune system, circulatory systems), and human diseases (1.0\%) (e.g. infectious diseases, metabolic diseases, neurodegenerative diseases) (Fig. 3, Additional file 5: Table S1).

A deeper analysis of the metabolism function module revealed that the most abundant genes were for the metabolism of amino acids (22.5\%) (e.g. alanine, aspartate,

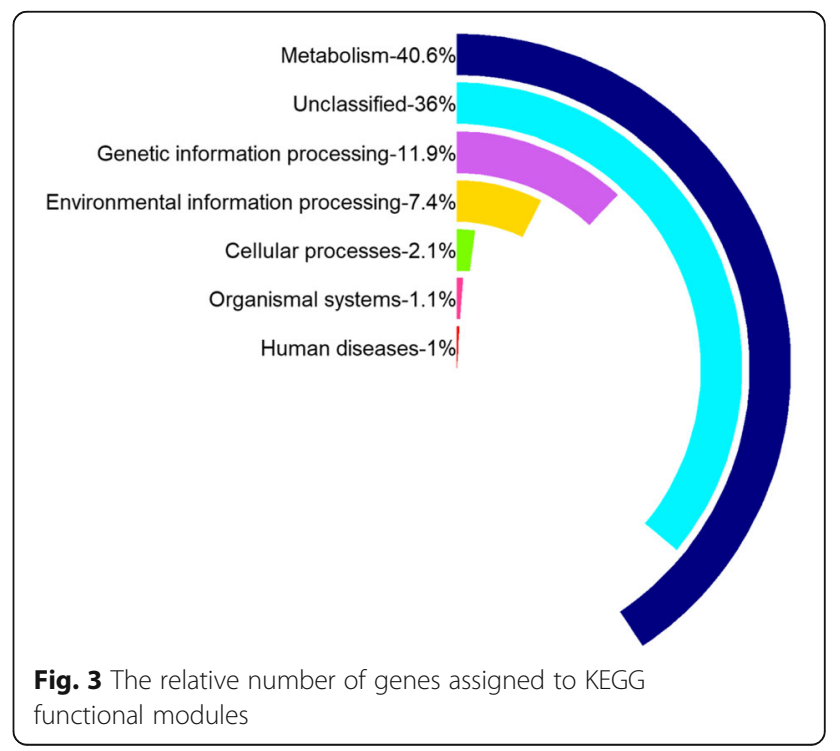


glutamate, glycine, serine and threonine), followed closely by carbohydrate metabolism (19.6\%) (e.g. glycolysis/gluconeogenesis, citrate cycle (TCA cycle), pentose phosphate pathway, starch and sucrose metabolism), energy metabolism (15.3\%) (e.g. oxidative phosphorylation, methane metabolism, nitrogen metabolism), nucleotide metabolism (10.5\%) (purine and pyrimidine metabolism), metabolism of cofactors and vitamins (9.9\%) (e.g. porphyrin and chlorophyll metabolism, pantothenate and $\mathrm{CoA}$ biosynthesis), metabolism of other amino acids (5.6\%) (e.g. selenocompound, glutathione and cyanoamino acid), lipid metabolism (5.0\%) (e.g. fatty acid degradation, fatty acid biosynthesis, glycerophospholipid metabolism), xenobiotics biodegradation and metabolism (4.7\%) (e.g. benzoate, 3 -chloroacrylic acid and nitrotoluene degradation), glycan biosynthesis and metabolism (2.5\%) (e.g. peptidoglycan biosynthesis, lipopolysaccharide biosynthesis, glycosaminoglycan degradation), biosynthesis of polyketides and terpenoids (2.7\%) (e.g. terpenoid backbone biosynthesis, limonene and pinene degradation, biosynthesis of ansamycins), and biosynthesis of other secondary metabolites (1.6\%) (e.g. streptomycin, novobiocin, and isoquinoline alkaloid biosynthesis) (Fig. 4, Additional file 5: Table S1, Additional file 6: Table S2).

As metabolism of amino acids and carbohydrates are common in all life forms, and to better understand how microbes thrive under energetically unfavorable conditions such as in caves, we therefore focused on other energy-producing metabolic pathways. Our results showed that the most abundant genes for these pathways are related to oxidative phosphorylation (28.8\%) (e.g. NADH-quinone oxidoreductase, cytochrome c oxidase, succinate dehydrogenase/fumarate reductase, flavoprotein subunit) (Fig. 5, Additional file 6: Table S2, Additional file 7: Table S3), and methane metabolism (20.5\%). Some of the identified functional genes that may encode by methanogens are: 5,10-methylenetetrahydromethanopterin reductase, tetrahydromethanopterin S-methyltransferase, and acetate kinase; and those encoded by methanotrophs are: methane monooxygenase and formate dehydrogenase (Fig. 5, Fig. 6, Additional file 6: Table S2, Additional file 8: Table S4). Also, genes involved in metabolism of carbon particularly of carbon fixation in prokatyotes were also detected (16.0\%) (e.g. 2-oxoglutarate ferredoxin oxidoreductase, pyruvate ferredoxin oxidoreductase, isocitrate dehydrogenase) (Fig. 5, Fig. 6, Additional file 6: Table S2, Additional file 9: Table S5). In addition, microbial genes involved in carbon fixation in photosynthetic organisms (9.7\%) (e.g. ribulose-bisphosphate carboxylase, fructosebisphosphate aldolase, ribose 5-phosphate isomerase) (Fig. 5, Additional file 6: Table S2, Additional file 10: Table S6) and photosynthetic pathway (4.0\%) (e.g. F-type $\mathrm{H}^{+}$-transporting ATPase, cytochrome b6-f complex ironsulfur subunit, photosystem II oxygen-evolving enhancer protein 1) were also detected in this community (Fig. 5, Additional file 6: Table S2, Additional file 11: Table S7). Moreover, the results also revealed functional genes involved in the nitrogen cycle (14.7\%) (Fig. 5, Fig. 6, Additional file 6: Table S2). The identified functional genes would be responsible for nitrification (e.g. ammonia monooxygenase, hydroxylamine dehydrogenase), denitrification (e.g. nitrate reductase, nitrite reductase (NOforming), periplasmic nitrate reductase), assimilatory and dissimilatory nitrate reduction (e.g. assimilatory nitrate reductase, nitrite reductase $(\mathrm{NADH})$, ferredoxinnitrite reductase) (Additional file 12: Table S8). Last but not least, microbial genes involved in sulfur metabolism (6.3\%) (e.g. sulfite reductase (NADPH) flavoprotein alpha and beta components, sulfite reductase (ferredoxin), sulfate adenylytransferase) were also found

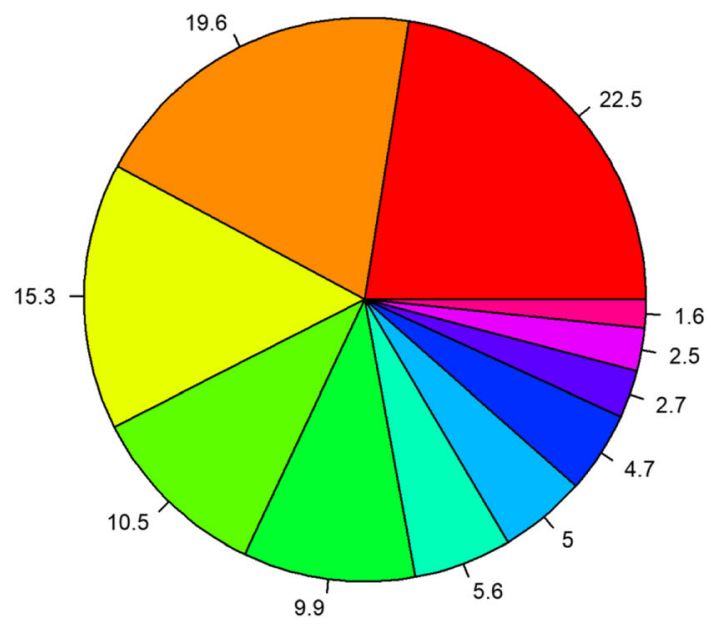

Amino acid metabolism

$\square$ Carbohydrate metabolism

$\square$ Energy metabolism

$\square$ Nucleotide metabolism

$\square$ Metabolism of cofactors and vitamins

$\square$ Metabolism of other amino acids

$\square$ Lipid metabolism

Xenobiotics biodegradation and metabolism

- Biosynthesis of polyketide and terpenoids

Glycan biosynthesis and metabolism

Biosynthesis of other secondary metabolites 


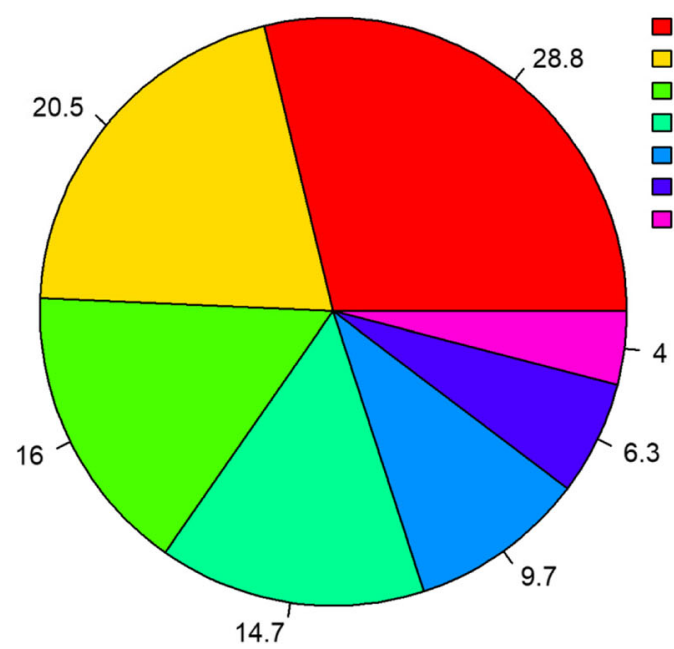

Oxidative phosphorylation

Methane metabolism

$\square$ Carbon fixation pathways in prokaryotes

$\square$ Nitrogen metabolism

Carbon fixation in photosynthetic organisms

Sulfur metabolism

Photosynthesis

(Fig. 5, Fig. 6, Additional file 6: Table S2, Additional file 13: Table S9).

Apart from the primary metabolites, microbial genes involved in other biological pathways of secondary metabolites were also identified. Specifically, $4.7 \%$ of the genes under the metabolism function module were for xenobiotic biodegradation and metabolism (Fig. 4, Additional file 5: Table S1). Among them, benzoate degradation via CoA ligation was the most abundant (19.5\%) (Additional file 6: Table S2). Other degradation pathways identified were: nitrotoluene degradation (7.3\%), geraniol degradation (6.2\%), 3-chloroacrylic acid degradation (5.9\%), other

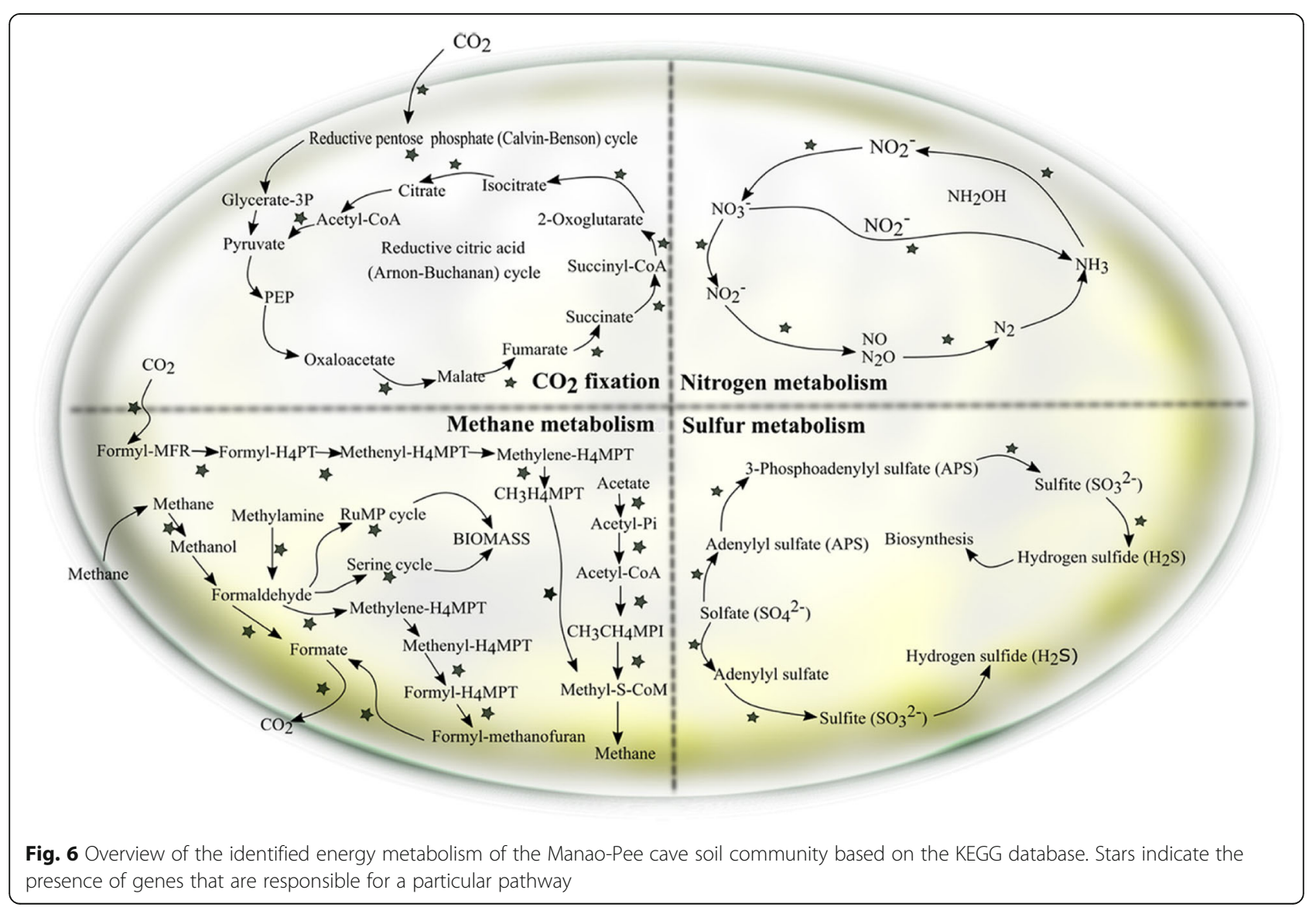


benzoate degradation (5.1\%), polycyclic aromatic hydrocarbon degradation (4.5\%), styrene degradation (4.4\%), chlorocyclohexane and chlorobenzene degradation (3.9\%), 1,2dichloroethane degradation (3.8\%), caprolactam degradation $(3.5 \%)$, atrazine degradation (2.9\%), aminobenzoate degradation $(2.3 \%)$, carbazole degradation $(2.0 \%)$, xylene degradation (1.6\%), ethylbenzene degradation (1.6\%), fluorobenzoate degradation (1.6\%), toluene degradation (1.5\%), and fluorene degradation (1.0\%). Moreover, metabolism of xenobiotics by cytochrome P450 (4.2\%), drug metabolism cytochrome P450 (4.5\%), and drug metabolism - other enzymes (11.0\%) were also detected (Additional file 6: Table S2). Except for xenobiotic biodegradation and metabolism, microbial genes involved in metabolism of terpenoids and polyketides were also detected (2.7\%) (Fig. 4, Additional file 5: Table S1). The most abundant biological pathway in metabolism of terpenoids and polyketides was terpenoid backbone biosynthesis (43.8\%) (Additional file 6: Table S2), followed by limonene and pinene degradation (14.0\%), biosynthesis of ansamycins (11.5\%), polyketide sugar unit biosynthesis (11.3\%), tetracycline biosynthesis (7.1\%), biosynthesis of vancomycin group antibiotics (6.0\%), biosynthesis of siderophore group nonribosomal peptides $(2.45 \%)$, zeatin biosynthesis (2.0\%), and carotenoid biosynthesis (1.1\%) (Additional file 6: Table S2). In addition, biosynthetic pathways of other compounds were also identified in this community (1.6\%) (Fig. 4, Additional file 5: Table S1), namely, streptomycin biosynthesis (35.1\%), novobiocin biosynthesis (14.1\%), tropane, piperidine and pyridine alkaloid biosynthesis (13.5\%), phenylpropanoid biosynthesis (13.1\%), isoquinoline alkaloid biosynthesis (9.5\%), penicillin and cephalosporin biosynthesis (5.1\%), butirosin and neomycin biosynthesis (3.9\%), stilbenoid, diarylheptanoid and gingerol biosynthesis (1.4\%), flavonoid biosynthesis (1.2\%), and betalain biosynthesis (1.1\%) (Additional file 6: Table S2).

\section{Discussion}

Analysis of microbial diversity in the cave soil community Cave habitats, in general, have unfavorable conditions to the development and support of life; nonetheless, caves do harbor a considerable diversity of microorganisms. Different groups of microorganisms can be found in caves such as bacteria, archaea, viruses, fungi, and protozoa [21, 23]. It has been suggested that "everything is everywhere, but the environment selects" [35, 36]. This would thus suggest that the unique characteristics of caves, i.e. their geological locations and physicochemical parameters, may influence microbial community structures and their ecological activity.

Previously, bacterial diversity in Manao-Pee cave soil community was explored using amplicon sequencing of 16S rRNA gene (V5-V6 regions) [27]. The microbial community structure of soil sample inside and outside the cave were totally different [27]. This suggested that conditions within caves can exclude those microbes that are not adapted to thrive under specific cave conditions. Consistent with the 16S rRNA-based community structure study, the shotgun metagenomic sequencing performed in the current study confirmed that Actinobacteria and Proteobacteria were the dominant bacterium phyla in Manao-Pee cave community (Additional file 14: Figure S5). Our observation is consistent with other studies which suggest that these two phyla are the cosmopolitan groups of bacteria in cave ecosystems [23, 24, 37, 38]. However, at a deeper taxonomic level, shotgun metagenomic sequencing provided increased resolution, enabling the detection of more microbial taxonomic profiles than 16S rRNA sequencing [27], especially of rare microorganisms. For example, at family level, 123 bacterial families were identified by shotgun sequencing, but only 55 families were detected by amplicon sequencing (Additional file 15: Figure S6a-d).

\section{Actinobacteria}

Actinobacteria are found in a wide variety of habitats including extreme environments [39-41]. Their success in these environments suggested that they have broad adaptive abilities, such as the capability of producing special metabolites (e.g. metal chelators, and antimicrobial compounds), as well as their profligate of secreted hydrolytic enzymes that may help in obtaining nutrient sources from various substrates [42, 43]. Furthermore, this group of bacteria also play an ecologically significant role in several ecological processes such as biogeochemical cycles (e.g nitrogen fixation, sulfur oxidization), bioremediation (e.g. clean up of soil contaminated with polycyclic aromatic hydrocarbons), bioweathering (e.g. speleothems formation), and plant growth promotion (e.g production of plant growth regulators, production of siderophores to enhance iron availability, promotion of symbiosis between nitrogen fixing bacteria or mycorrhiza and plants) [23, 39, 44-49]. In cave microbiomes, they are not only found dominating in soil and sediments [24], but are also the prominent group on the cave walls, stalactites, and stalagmites [21, 38]. Using scanning electron microscopy, members of Actinobacteria are found to promote mineral dissolution and precipitation $[23,50]$, suggesting that this group of bacteria play a significant role in the formation of secondary mineral deposits which was previously viewed as an abiotic reaction. As the Actinobacteria phylum constitute the bulk of cave microbial communities, such habitats appear to favour this group of bacteria [23]. It has been speculated that their highly prolific source of secondary metabolites could be a driving factor for them to thrive under energetically unfavorable and nutrient-limited conditions [42]. 
Actinobacteria especially of the genus Streptomyces have long been recognized to produce pharmaceutically important bioactive molecules [51, 52]. As there is a decline in the discovery of novel bioactive molecules from Streptomyces in the past two decades [53], intensive efforts have focused on finding bioactive molecules derived from Actinobacteria from extreme or underexplored habitats such as caves, deserts, hot springs, and deep-sea sediments [39, 42, 54]. In this study, apart from Streptomyces spp., we also identified the presence of rare Actinobacteria (e.g. Mycobacterium, Nocardioides, Marmoricola, Crossiella, Amycolatopsis, Nocardia, Pseudonocardia, and Saccharopolyspora) in Manao-Pee cave. These groups of microorganisms are of particular interest as they are likely to harbor biosynthetic pathways of novel bioactive compounds [27, 55].

\section{Proteobacteria}

It is known that Proteobacteria constitutes the largest and most diverse group within the domain bacteria [56]. This group inhabits diverse ecological niches [57], and is one of the most prevalent groups in cave ecosystems $[21,24,58]$. It is also known that Proteobacteria play an important ecological role in energy generating metabolisms (e.g. carbon fixation, nitrogen metabolism and sulfur metabolisms) $[56,57]$. In the current study, among the five classes of Proteobacteria, the Gammaproteobacteria was the most prevalent in Mano-Pee cave soil community, with the most common genus belonging to Salinisphaera (6.6\%), Lysobacter (6.1\%), and Xanthomonas (5.5\%). It has been well documented that this class harbors metabolically and ecologically diverse chemolithoautotrophs that can use a variety of inorganic molecules as an electron source [21]. Thus, they might play a vital role in sustaining diverse groups of other microorganisms in this ecosystem.

\section{Metabolic potential analysis of Manao-Pee cave soil community}

A metabolic potential analysis provides new opportunities to bridge the knowledge gap in the field of microbial ecology. As opposed to microbial profiling information, knowledge regarding metabolic potential of cave-dwelling microorganisms is very limited. The results of such a study will provide molecular biological evidence to increase our understanding of how cave microorganisms adapt and thrive under unfavorable conditions. Moreover, a metabolic potential investigation of cave microorganisms may also be applicable for applied research as well since the information obtained should provide leads to novel and useful microbial metabolites.

\section{Energy metabolism}

Obtaining sufficient energy is one of most important ecological processes for survival of any organism. Ecologically, it is generally known that photosynthesis is the primary energy producing process on our planet [25]. Microbial communities in terrestrial ecosystems are also directly or indirectly dependent on energy and organic carbon that ultimately originated from this process. One of a few exceptions is the cave ecosystem. Devoid of light, although allochonous organic material can derive from photic surface environment [21, 42], microbes have to rely on alternate non-photosynthetic primary production strategies in order to thrive under unfavourable conditions. It has been reported that in caves, chemolithoautotrophic microbes are important as they obtain energy from the oxidation of inorganic molecules which in turn support the growth of other microbial populations [59]. Our study showed that the most abundant functional genes were for oxidative phosphorylation. This is not surprising, as it is the major metabolic pathway providing energy for the majority of aerobic organisms. Moreover, the microbial genes encoding methane metabolism, carbon fixation, nitrogen metabolism, sulfur metabolism, and photosynthesis were also identified in the cave soil community.

\section{Methane metabolism}

Methane is one of the key elements in the global carbon cycle. Some microorganisms can obtain their energy from methane production, some can even use this molecule as an energy and carbon source [60, 61]. Our results suggesedt that methanogenic (e.g. Euryarchaeota, Methylobacillus, Methylophaga) and methanotrophic microbes (e.g. Methylobacter, Methylococcus, Methylomicrobium) can be found in the Manao-Pee cave soil community.

Methanogenic organisms can anaerobically obtain energy for growth by converting the limited number of substrates to methane as a metabolic byproduct. Most of these bacteria belong to the archaeal domain in the phylum Euryarchaeota [61] and can be found thriving in extreme habitats (e.g. deep soil sediments) [62]. It is known that there are three major methanogenesis pathways based on cabon sources $\left(\mathrm{H}_{2}+\mathrm{CO}_{2}\right.$ or formate (hydrogenotrophic methanogenesis), methyl-containing C-1 compounds (methylotrophic methanogenesis), and acetate (aceticlastic methanogenesis) [61, 63]. Due to the limited number of organic carbon sources in the caves, methane might be one of the energy-rich molecules that drive the microbial community.

Methanotrophic microorganisms can use methane as their sole carbon and energy source [60]. This biological pathway can be carried out under aerobic or anaerobic conditions. It has been reported that aerobic methanotrophic Gammaproteobacteria, Alphaproteobacteria, and Verrucomicrobia play a vital role in methane oxidation [64]. When oxygen is present, methane is converted to methanol and then to formaldehyde. Instead of being 
oxidized to carbon dioxide for energy generation, formaldehyde can also be assimilated into the cell's biomass by means of ribulose monophosphate (RuMP) pathway or the serine pathway [60]. In this study, one of the key enzymes of this process, membrane-bound particulate methane monooxygenase (pMMO), which is the common MMO in aerobic methanotrophs was found. The results of our work suggested that methanogens and methanotrophs might play important ecological roles in sustaining diverse microbial communities in the ManaoPee cave as well.

\section{Carbon fixation}

Carbon fixation is an essential process in a microbial community through which inorganic carbon is incorporated into organic molecules [65]. In addition to photoautotrophic microorganisms, chemoautotrophic microorganisms can also carry out this process $[65,66]$. So far, at least six autotrophic $\mathrm{CO}_{2}$ fixation pathways are known and different microorganisms generally utilize different fixation pathways [67]. All six $\mathrm{CO}_{2}$ fixation pathways are found on the speleothem surfaces in the Kartchner Caverns (Arizona, USA), with the predominant pathways being the Calvin-BensonBassham (CBB) and the reductive citric acid cycle (ArnonBuchanan) [25]. In our study, genes encoding the reductive citric acid cycle were predominant $(>50 \%)$ in the ManaoPee cave soil community. Surprisingly, since soil samples were collected from the dark areas deep inside the cave, functional genes involved in photosynthetic pathway and carbon fixation in photosynthetic organisms were also found. Concurrent with the result of microbial diversity analysis, algae and Cyanobacteria were also found in this community. They might contribute to the presence of the photosynthetic pathway as they usaually use this process to fix $\mathrm{CO}_{2}$ into biomass. [67]. Another possible reason is the presence of light-harvesting green-sulfur photoautotrophic bacteria (Chlorbi, Chloroflexi). It has been reported that these groups of microbes can obtain energy via photosynthesis at extremely low light intensities at which no other photosynthetic organisms can grow [68]. In addition, organisms capable of carrying out photosynthesis are also found in other phyla of bacteria: Acidobacteria, Firmicutes, Gemmatimonadetes, and Proteobacteria [69]. Members of those phyla that powered by light were also identified in this community (e.g. Rhodospirillum, Ectothiorhodospira, Thiocapsa). Moreover, it was reported that key proteins required for photosynthesis are also present in Rubrobacter (phylum Actinobacteria) [70]. Due to the physical characteristics of the Manao-Pee cave, those photoautotrophic microorganisms from the overlaying surface might enter the cave via the sinkhole. However, in the cave environment, photosynthetic genes may or may not be active, or the genes might exist and be only anciently presented within their genome.

\section{Nitrogen metabolism}

Nitrogen is one of the most important elements for all life forms on our planet [71]. Microorganisms are the major contributor of nitrogen cycling, since it has been reported that atmospheric nitrogen, nitrate, nitrite, ammonium, and glutamine are widely used by microorganisms in environments [72]. However, most nitrogen on our planet is in the form of nitrogen gas $\left(\mathrm{N}_{2}\right)$ which is not biologically available to support life [73] . Thus, nitrogen fixation by certain groups of bacteria and archaea (diazotrophs) is an important process by which atmospheric nitrogen is converted to ammonia available to other organisms [74]. From the study of the Frasassi caves (Italy) ecosystem, nitrogen fixation via nitrogenase activity is found in the cave waters [74]. However, in the present study, nitrogenase genes were not detected. Nonetheless, other subsystems related to nitrogen metabolism, including nitrification (e.g. ammonia monooxygenase, hydroxylamine dehydrogenase), denitrification (e.g. nitrate reductase, nitrite reductase (NO-forming), periplasmic nitrate reductase), assimilatory and dissimilatory nitrate reduction (e.g. assimilatory nitrate reductase, nitrite reductase (NADH), ferredoxin-nitrite reductase) were found in this community. These ecologically important processes might have critical roles in sustaining the microbial community within the cave ecosystem.

\section{Sulfur metabolism}

Sulfur is another one the most abundant elements on Earth [75]. The biological transformation of inorganic sulfur can be performed by bacteria and archaea for the generation and conservation of biological energy [76]. These groups of microbes usually live in a symbiotic relationship with anaerobic methanotrophs as hydrogen generated from anaerobic methane oxidation can be used to drive redox reactions of inorganic sulfur [60]. However, in a soil habitat, sulfate $\left(\mathrm{SO}_{4}{ }^{2-}\right)$ is the most oxidized and accessible form of sulfur for microoganisms [77]. In our study, the most identified genes (e.g. sulfite reductase, phosphoadenosine phosphosulfate reductase, sulfate adenylyltransferase, adenylylsulfate reductase) are responsible for sulfate reduction (energy consuming assimilatory pathway or energy producing dissimilatory pathway). Concurrent with microbial diversity information, sulfate-reducing microorganisms were also identified (e.g. Desulfovibrio, Desulfonatronospira, Desulfatibacilium, Thermodesulfobium). One of the identified genes in the assimilatory sulfate reduction pathway was sulfite reductase which catalyses the six-electron reduction of sulfite to hydrogen sulfide and water. This pathway is widely used by bacteria, fungi, and photosynthetic organisms to convert inorganic sulfate to sulfide which can be further incorporated into a carbon skeleton of sulfur-containing amino acids and proteins [78]. Apart from an energy 
consuming assimilatory pathway, microorganisms can also use sulfate as an alternative electron acceptor in the absence of oxygen. This biological pathway, dissimilatory sulfate reduction, serves as energy-yielding reactions for growth [75]. This suggested that in Manao-Pee cave, microorganisms involved in the sulfur cycle may also serve as one of the primary producers in the cave food web.

\section{Xenobiotic biodegradation and metabolism in Manao- Pee cave microbiome}

Xenobiotic is a term referring to unnatural or foreign compounds, including polycyclic hydrocarbons, pollutants, antibiotics, polyaromatic, chlorinated and nitroaromatic compounds found in the biosphere [79, 80]. Some of these compounds can be very toxic, but can be transformed into less toxic compounds by various biological pathways $[81,82]$. It has been reported that stress or low nutrient habitats can force living microoganisms to use any available nutrients to survive [83]; thus, cavedwelling microroganisms may use the by-products of xenobiotic biodegradation for energy, nutrients, or final electron acceptors for their growth [79]. For instance, it has been reported that various bacteria (Serratia sp. KC1-MRL, Bacillus liceniformis KC2-MRL, Bacillus sp. KC3-MRL, Stenotrophomonas sp. KC4-MRL) isolated from soil samples of Kashmir Smast, a limestone cave in Khyber Pakhtoonkhuwa province, Pakistan, are capable of degrading polyethylene [83]. Therefore, it is also likely that xenobiotic biodegradation and metabolism might be another important process in sustaining diverse groups of microorganisms in Manao-Pee cave.

\section{Natural secondary metabolites production in Manao- Pee cave microbiome}

In their natural environments, microbes usually form complex ecological networks, consisting of many species either directly or indirectly interacting with one another [84]. These networks interplay, potentially mediated by bacterial secondary metabolites, may result in successful establishment and maintenance of microbial populations [85].

Microorganisms produce a large variety of secondary metabolites. Even though production of these compounds is not considered essential for normal growth and development, it nonetheless provides essential ecological benefits [86]. Ecologically, secondary metabolites may contribute to both cooperative and competitive interactions among microoganisms [87]. Certain microbes, for example, produce secondary metabolites to compete with one another for limited resources [85]. Due to the nutrient-limited nature of a cave environment, it has been hypothesized that competition for natural resources might be the dominant adaptation of cave microbiome [37, 88]. Yet, at sub-optimal concentrations, secondary metabolites can also be used as signaling molecules (e.g. kanamycin, gentamycin, tetracycline) to help in inter- or intraspecies communications [85, 89]. In a cave microbiome, it is unlikely that all reactions necessary for growth and obtaining energy from complex inorganic molecules are carried out by a single species [21]. Thus, signaling molecules are needed to mediate cooperative and mutualistic actions among cave microorganisms; thereby, increasing the likelihood of survival under energetically unfavorable environments.

Among microbial secondary metabolites, antibiotics are of special interest. Due to the rise of antibiotic resistant pathogens [90], novel antibiotics discovery is essential. In recent years, there have been rigorous efforts to find new bioactive compounds from cave microbiomes because it is believed that the less studied cave environment might be a potential source for drug discovery [91-93].

\section{Conclusion}

Microorganisms are key players in every environmental niches. Their taxonomic and functional distribution are selected for directly or indirectly by environmental factors. In this work we confirmed that Manao-Pee cave harbored a great diversity of bacteria, with the most dominant groups being Actinobacteria and Gammaproteobacteria. Metabolic functional analysis revealed microbial genes involved in various metabolic pathways. To survive under energetically unfavorable and nutrientlimited conditions, methane metabolism, carbon fixation, nitrogen metabolism, sulfur metabolism, xenobiotic biodegradation and metabolism, and secondary metabolite production all might play important ecological roles in sustaining the diverse groups of microorganisms. Beyond providing information on microbial diversity and associated metabolic potential for survival under the cave conditions and to better understand life in the hidden world, our study also suggested that unique bioactive molecules with promising activity in medical and industrial processes may also be obtained from Manao-Pee cave.

\section{Additional files}

Additional file 1: Figure S1. Distribution of Actinobacteria in the soil community of Manao-Pee cave at (a) family level and (b) genus level. Percentage values represent the relative abundance of ribosomal RNA genes assigned to a particular taxon. (DOCX $623 \mathrm{~kb}$ )

Additional file 2: Figure S2. Distribution of Proteobacteria in the soil community of Manao-Pee cave at (a) class level, (b) family level, and (c) genus level. Percentage values represent the relative abundance of ribosomal RNA genes assigned to a particular taxon. (DOCX 761 kb)

Additional file 3: Figure S3. Distribution of archaeal phylum in the soil community of Manao-Pee cave. Percentage values represent the relative abundance of ribosomal RNA genes assigned to a particular taxon. (DOCX $110 \mathrm{~kb})$ 
Additional file 4: Figure S4. Distribution of eukaryotic organisms in the soil community of Manao-Pee cave. Percentage values represent the relative abundance of ribosomal RNA genes assigned to a particular taxon. (DOCX $147 \mathrm{~kb}$ )

Additional file 5: Table S1. The number of genes assigned to the various sub-functional modules. (DOCX $14 \mathrm{~kb}$ )

Additional file 6: Table S2. The relative number of genes assigned to the various biological pathways. (DOCX $27 \mathrm{~kb}$ )

Additional file 7: Table S3. The identified microbial genes involved in the oxidative phosphorylation pathway. (DOCX $17 \mathrm{~kb}$ )

Additional file 8: Table S4. The identified microbial genes involved in methane metabolism pathway. (DOCX $16 \mathrm{~kb}$ )

Additional file 9: Table S5. The identified microbial genes involved in carbon fixation pathways in prokaryotes. (DOCX $15 \mathrm{~kb}$ )

Additional file 10: Table S6. The identified microbial genes involved in carbon fixation from photosynthetic organisms. (DOCX $14 \mathrm{~kb}$ )

Additional file 11: Table S7. The identified microbial genes involved in the photosynthetic pathway. (DOCX $14 \mathrm{~kb}$ )

Additional file 12: Table S8. The identified microbial genes involved in nitrogen metabolism pathway. (DOCX $16 \mathrm{~kb}$ )

Additional file 13: Table S9. The identified microbial genes involved in sulfur metabolism pathway. (DOCX $15 \mathrm{~kb}$ )

Additional file 14: Figure S5. Comparison of bacterial diversity in the soi community of Manao-Pee cave at the phylum level by 165 rRNA sequencing versus shotgun metagenomic sequencing. Both techniques, at this taxonomic depth, gave comparable results, revealing that most Manao-Pee cave microbes belonged to the phyla Actinobacteria or Proteobacteria. (DOCX $950 \mathrm{~kb}$ )

Additional file 15: Figure S6. Comparison of bacterial diversity in the soil community of Manao-Pee cave at (a) class, (b) order, (c) family, and (d) genus level by amplicon sequencing versus shotgun metagenomic sequencing. In general, at deeper taxonomic levels, shotgun metagenomic sequencing gave more insight into the numbers and identity of microbial present. (DOCX $12712 \mathrm{~kb}$ )

\section{Abbreviations}

eDNA: Environmental DNA; KEGG: Kyoto Encyclopedia of Genes and Genomes; OTU: Operational taxonomic unit; rRNA: Ribosomal RNA

\section{Acknowledgements}

We greatly acknowledged the Agriculture and Cooperative Division of the Royal Thai Armed Forces Development Command, Kanchanaburi province, for their help in accessing the study area. We thanked Pitchapat Hanprab, Dr. Supajit Sraphet, Nawarat Suksee, and lab members for help with collecting samples. In addition, we would like to thank Dr. Albert Ketterman for his careful and critical reading of the manuscript.

\section{Authors' contributions}

AW performed samples collection, conducted the experimental works, interpreted the results, and wrote the manuscript. WM carried out bioinformatic analysis. ST performed shotgun sequencing. DC supervised shotgun sequencing and provided technical support. KP was responsible for the primary conception of the study, supervised and edited the manuscript. All authors read and approved the final manuscript.

\section{Funding}

This study is supported by the Thailand Research Fund through the Royal Golden Jubilee Ph.D. Program (Grant No. PHD/0029/2557), the Plant Genetic Conservation Project under the Royal Initiation of Her Royal Highness Princes Maha Chakri Sirindhorn (RSPG) and Mahidol University. The funders were not involved in the design of the study, collection, analysis, and interpretation of data, nor in preparation of this manuscript.

\section{Availability of data and materials}

All datasets present in the research article were submitted to the NCBI Sequence Read Archive under the accession number PRJNA485054

\section{Ethics approval and consent to participate}

The permission to enter the study sites and to collect the samples was obtained from the Department of National Parks, Wildlife and Plant Conservation, Thailand.

\section{Consent for publication}

Not applicable.

\section{Competing interests}

The authors declare that they have no competing interests.

\section{Author details}

${ }^{1}$ Institute of Molecular Biosciences, Mahidol University, Salaya Campus, Phuttamonthon 4 Rd, Salaya, Nakhon Pathom 73170, Thailand. ${ }^{2}$ National Center for Genetic Engineering and Biotechnology (BIOTEC), 133 Thailand Science Park, Paholyothin Rd, Klong 1, Klongluang, Pathumthani 12120, Thailand.

Received: 4 October 2018 Accepted: 19 June 2019

Published online: 27 June 2019

\section{References}

1. Sunagawa S, Mende DR, Zeller G, Izquierdo-Carrasco F, Berger SA, Kultima JR, Coelho LP, Arumugam M, Tap J, Nielsen HB, Rasmussen S, Brunak S, Pedersen O, Guarner F, de Vos WM, Wang J, Li J, Dore J, Ehrlich SD, Stamatakis A, Bork P. Metagenomic species profiling using universal phylogenetic marker genes. Nat Methods. 2013;10(12):1196-9.

2. Ghilamicael AM, Budambula NLM, Anami SE, Mehari T, Boga HI. Evaluation of prokaryotic diversity of five hot springs in Eritrea. BMC Microbiol. 2017:17:203.

3. Ranjan R, Rani A, Metwally A, McGee HS, Perkins DL. Analysis of the microbiome: advantages of whole genome shotgun versus 165 amplicon sequencing. Biochem Biophys Res Commu. 2016;469(4):967-77.

4. Hao X, Chen T. OTU analysis using metagenomic shotgun sequencing data. PLoS One. 2012;7(11):e49785.

5. Brooks JP, Edwards DJ, Harwich MD, Rivera MC, Fettweis JM, Serrano MG, Reris RA, Sheth NU, Huang B, Girerd P. Strauss JF, Jefferson KK, Buck GA. The truth about metagenomics: quantifying and counteracting bias in 165 rRNA studies. BMC Microbiol. 2015;15:66

6. Fierer N, Leff JW, Adams BJ, Nielsen UN, Bates ST, Lauber CL, Owens S, Gilbert JA, Wall DH, Caporaso JG. Cross-biome metagenomic analyses of soil microbial communities and their functional attributes. PNAS. 2012;109(52): 21390-5.

7. Poretsky R, Rodriguez-R LM, Luo C, Tsementzi D, Konstantinidis KT. Strengths and limitations of $16 \mathrm{~S}$ rRNA gene amplicon sequencing in revealing temporal microbial community dynamics. PLoS One. 2014;9(4): e93827.

8. Sharpton TJ. An introduction to the analysis of shotgun metagenomic data. Front Plant Sci. 2014;5:209.

9. Zhou J, He Z, Yang Y, Deng Y, Tringe SG, Alvarez-Cohen L. High-throughput metagenomic technologies for complex microbial community analysis: open and closed formats. mBio. 2015;6:1.

10. Steele HL, Streit WR. Metagenomics: advances in ecology and biotechnology. FEMS Microbiol Lett. 2005;247(2):105-11.

11. Langille MGI, Zaneveld J, Caporaso JG, McDonald D, Knights D, Reyes JA, Clemente JC, Burkepile DE, Vega Thurber RL, Knight R, Beiko RG, Huttenhower C. Predictive functional profiling of microbial communities using 16S rRNA marker gene sequences. Nat Biotech. 2013;31(9):814-21.

12. Aßhauer KP, Wemheuer B, Daniel R, Meinicke P. Tax4Fun: predicting functional profiles from metagenomic 165 rRNA data. Bioinformatics. 2015; 31(17):2882-4.

13. Nagpal S, Haque MM, Mande SS. Vikodak - a modular framework for inferring functional potential of microbial communities from 165 metagenomic datasets. PLoS One. 2016;11(2):e0148347.

14. Alexandre $\mathrm{G}$, Greer-Phillips $\mathrm{S}$, Zhulin IB. Ecological role of energy taxis in microorganisms. FEMS Microbiol Rev. 2004;28(1):113-26.

15. Eisen JA. Environmental shotgun sequencing: its potential and challenges for studying the hidden world of microbes. PLoS Biol. 2007:5(3):e82.

16. Hillmann B, Al-Ghalith GA, Shields-Cutler RR, Zhu Q, Gohl DM, Beckman KB, Knight $R$, Knights $D$. Evaluating the information content of shallow shotgun metagenomics. mSystems. 2018;3(6):e00069-18. 
17. Peabody MA, Van Rossum T, Lo R, Brinkman FSL. Evaluation of shotgun metagenomics sequence classification methods using in silico and in vitro simulated communities. BMC Bioinformatics. 2015;16:362.

18. Bragg LM, Stone G, Butler MK, Hugenholtz P, Tyson GW. Shining a light on dark sequencing: characterising errors in ion torrent PGM data. PLOS Comput Biol. 2013;9(4):e1003031.

19. Clooney AG, Fouhy F, Sleator RD, O'Driscoll A, Stanton C, Cotter PD, Claesson MJ. Comparing apples and oranges?: next generation sequencing and its impact on microbiome analysis. PLoS One. 2016;11(2):e0148028.

20. Riquelme C, Enes Dapkevicius MdL, Miller AZ, Charlop-Powers Z, Brady S, Mason C, Cheeptham N. Biotechnological potential of Actinobacteria from Canadian and Azorean volcanic caves. Appl Microbiol Biotechnol 2017; 101(2):843-857.

21. Tomczyk-Żak K, Zielenkiewicz U. Microbial diversity in caves. Geomicrobiol J. 2016:33(1):20-38.

22. Maciejewska M, Adam D, Naome A, Martinet L, Tenconi E, Calusinska M, Delfosse P, Hanikenne M, Baurain D, Compere P, Carnol M, Barton H, Rigali S. Assessment of the potential role of Streptomyces in cave moonmilk formation. Front Microbiol. 2017:8:1181.

23. Cuezva S, Fernandez-Cortes A, Porca E, Pasic L, Jurado V, Hernandez-Marine M. Serrano-Ortiz P, Hermosin B, Canaveras JC, Sanchez-Moral S, Saiz-Jimenez C. The biogeochemical role of Actinobacteria in Altamira cave, Spain. FEMS Microbiol Ecol. 2012;81(1):281-90.

24. De Mandal S, Chatterjee R, Kumar NS. Dominant bacterial phyla in caves and their predicted functional roles in C and N cycle. BMC Microbiol. 2017;17:90.

25. Ortiz M, Legatzki A, Neilson JW, Fryslie B, Nelson WM, Wing RA, Soderlund CA, Pryor BM, Maier RM. Making a living while starving in the dark: metagenomic insights into the energy dynamics of a carbonate cave. ISME J. 2014;8(2):478-91.

26. Zepeda Mendoza ML, Lundberg J, Ivarsson M, Campos P, Nylander JAA, Sallstedt T, Dalen L. Metagenomic analysis from the interior of a speleothem in Tjuv-Ante's cave, northern Sweden. PLoS One. 2016;11(3): e0151577

27. Wiseschart A, Mhuanthong W, Thongkam P, Tangphatsornruang S, Chantasingh D, Pootanakit K. Bacterial diversity and phylogenetic analysis of type II polyketide synthase gene from Manao-Pee cave, Thailand. Geomicrobiol J. 2018;35(6):518-27.

28. Sambrook J, Russell DW. Molecular cloning: a laboratory manual: cold Spring Harbor laboratory press; 2001.

29. Cock PJA, Fields CJ, Goto N, Heuer ML, Rice PM. The sanger FASTQ file format for sequences with quality scores, and the Solexa/lllumina FASTQ variants. Nucleic Acids Res. 2010;38(6):1767-71.

30. Zhu W, Lomsadze A, Borodovsky M. Ab initio gene identification in metagenomic sequences. Nucleic Acids Res. 2010;38(12):e132

31. Zhao $Y$, Tang $H$, Ye $Y$. RAPSearch2: a fast and memory-efficient protein similarity search tool for next-generation sequencing data. Bioinformatics. 2012;28(1):125-6.

32. Suzek BE, Wang Y, Huang H, McGarvey PB, Wu CH. UniRef clusters: a comprehensive and scalable alternative for improving sequence similarity searches. Bioinformatics. 2015;31(6):926-32.

33. Huson DH, Auch AF, Qi J, Schuster SC. MEGAN analysis of metagenomic data. Genome Res. 2007;17(3):377-86.

34. Quast C, Pruesse E, Yilmaz P, Gerken J, Schweer T, Yarza P, Peplies J, Glöckner FO. The SILVA ribosomal RNA gene database project: improved data processing and web-based tools. Nucleic Acids Res. 2013;41(Database issue):D590-D96

35. Tang H, Shi X, Wang X, Hao H, Zhang X-M, Zhang L-P. Environmental controls over Actinobacteria communities in ecological sensitive Yanshan Mountains zone. Front Microbiol. 2016;7:343.

36. O'Malley MA. 'Everything is everywhere: but the environment selects': ubiquitous distribution and ecological determinism in microbial biogeography. Stud History Philosophy Sci Part C. 2008;39(3):314-25.

37. Lavoie K, Ruhumbika T, Bawa A, Whitney A, de Ondarza J. High levels of antibiotic resistance but no antibiotic production detected along a gypsum gradient in great Onyx cave, KY, USA. Diversity. 2017;9:4.

38. Ortiz M, Neilson J, Nelson W, Legatzki A, Byrne A, Yu Y, Wing R, Soderlund C, Pryor B, Pierson L III, Maier R. Profiling bacterial diversity and taxonomic composition on speleothem surfaces in Kartchner caverns, AZ. Microb Ecol. 2013;65(2):371-83.

39. Shivlata L, Tulasi S. Thermophilic and alkaliphilic Actinobacteria: biology and potential applications. Front Microbiol. 2015;6:1014.
40. Idris H, Goodfellow M, Sanderson R, Asenjo JA, Bull AT. Actinobacterial rare biospheres and dark matter revealed in habitats of the Chilean Atacama Desert. Sci Rep. 2017;7:8373.

41. Cantillo A, Shapiro N, Woyke T, Kyrpides NC, Baena S, Zambrano MM. Genome sequences of Actinobacteria from extreme environments in Colombia. Microbiol Resour Announc. 2018;7(22):e01384-18.

42. Maciejewska M, Adam D, Martinet L, Naômé A, Całusińska M, Delfosse $P$, Carnol M, Barton HA, Hayette M-P, Smargiasso N, De Pauw E, Hanikenne M, Baurain D, Rigali S. A phenotypic and genotypic analysis of the antimicrobial potential of cultivable Streptomyces isolated from cave moonmilk deposits. Front Microbiol. 2016;7:1455.

43. Maciejewska M, Calusinska M, Cornet L, Adam D, Pessi IS, Malchair S, Delfosse P, Baurain D, Barton HA, Carnol M, Rigali S. High-throughput sequencing analysis of the actinobacterial spatial diversity in moonmilk deposits. Antibiotics (Basel). 2018;7(2):27.

44. Chen M, Xu P, Zeng G, Yang C, Huang D, Zhang J. Bioremediation of soils contaminated with polycyclic aromatic hydrocarbons, petroleum, pesticides, chlorophenols and heavy metals by composting: applications, microbes and future research needs. Biotechnol Adv. 2015:33(6):745-55.

45. Cockell CS, Kelly LC, Marteinsson V. Actinobacteria —an ancient phylum active in volcanic rock weathering. Geomicrobiol J. 2013;30(8):706-20.

46. Palaniyandi SA, Yang SH, Zhang L, Suh J-W. Effects of Actinobacteria on plant disease suppression and growth promotion. Appl Microbiol Biotechnol. 2013;97(22):9621-36.

47. Tisato N, Torriani SFF, Monteux S, Sauro F, De Waele J, Tavagna ML, D'Angeli IM, Chailloux D, Renda M, Eglinton TI, Bontognali TRR. Microbial mediation of complex subterranean mineral structures. Sci Rep. 2015;5:15525.

48. Norris PR, Davis-Belmar CS, Brown CF, Calvo-Bado LA. Autotrophic, sulfuroxidizing Actinobacteria in acidic environments. Extremophiles. 2011;15(2): 155-63.

49. Sathya A, Vijayabharathi R, Gopalakrishnan S. Plant growth-promoting Actinobacteria: a new strategy for enhancing sustainable production and protection of grain legumes. 3 Biotech. 2017;7(2):102.

50. Riquelme C, Marshall Hathaway JJ, Enes Dapkevicius MDL, Miller AZ, Kooser A, Northup DE, Jurdo V, Fernandaz O, Saiz-Jimenez C, Cheeptham N. Actinobacterial diversity in volcanic caves and associated geomicrobiological interactions. Front Microbiol. 2015;6:1342.

51. Rateb ME, Houssen WE, Harrison WTA, Deng H, Okoro CK, Asenjo JA, Andrews BA, Bull AT, Goodfellow M, Ebel R, Jaspars M. Diverse metabolic profiles of a Streptomyces strain isolated from a hyper-arid environment. J Nat Prod. 2011;74(9):1965-71.

52. Ward AC, Allenby NE. Genome mining for the search and discovery of bioactive compounds: the Streptomyces paradigm. FEMS Microbiol Lett. 2018;365:24.

53. Genilloud O. Actinomycetes: still a source of novel antibiotics. Nat Prod Rep. 2017;34(10):1203-32.

54. Sarmiento-Vizcaíno A, Braña FA, Pérez-Victoria I, Martín J, De Pedro N, Cruz DM, Díaz C, Vicente F, Acuña LJ, Reyes F, García AL, Blanco G. Paulomycin g, a new natural product with cytotoxic activity against tumor cell lines produced by deep-sea sediment derived Micromonospora matsumotoense M-412 from the Avilés canyon in the Cantabrian Sea. Mar Drugs. 2017;15(9): 271.

55. Tiwari K, Gupta RK. Rare actinomycetes: a potential storehouse for novel antibiotics. Crit Rev Biotechnol. 2012;32(2):108-32.

56. Kersters K, De Vos P, Gillis M, Swings J, Vandamme P, Stackebrandt E. Introduction to the Proteobacteria. In: Dworkin M, Falkow S, Rosenberg E, Schleifer K-H, Stackebrandt E, editors. The prokaryotes: volume 5: Proteobacteria: alpha and beta subclasses. New York: Springer New York; 2006. p. 3-37.

57. Spain AM, Krumholz LR, Elshahed MS. Abundance, composition, diversity and novelty of soil Proteobacteria. ISME J. 2009;3:992-1000.

58. Oliveira C, Gunderman L, Coles AC, Lochmann J, Parks M, Ballard E, Glazko G, Rahmatallah Y, Tackett AJ, Thomas DJ. 16S rRNA gene-based metagenomic analysis of Ozark cave bacteria. Diversity (Basel). 2017:9:31.

59. Chen Y, Wu L, Boden R, Hillebrand A, Kumaresan D, Moussard H, Baciu M, Lu Y, Colin MJ. Life without light: microbial diversity and evidence of sulfur- and ammonium-based chemolithotrophy in Movile cave. ISME J. 2009;3(9):1093-104.

60. Kang TJ, Lee EY. Metabolic versatility of microbial methane oxidation for biocatalytic methane conversion. J Ind Eng Chem. 2016;35:8-13.

61. Liu Y, Beer LL, Whitman WB. Methanogens: a window into ancient sulfur metabolism. Trends Microbiol. 2012;20(5):251-8. 
62. Taubner R-S, Schleper C, Firneis MG, Rittmann SKMR. Assessing the ecophysiology of methanogens in the context of recent astrobiological and planetological studies. Life (Basel). 2015;5(4):1652-86.

63. Lyu Z, Shao N, Akinyemi T, Whitman WB. Methanogenesis. Curr Biol. 2018; 28(13):727-32.

64. Waring CL, Hankin SI, Griffith DWT, Kertesz MA, Kobylski V, Wilson NL, Coleman NV, Kettlewell G, Zlot R, Bosse M, Bell G. Seasonal total methane depletion in limestone caves. Sci Rep. 2017;7:8314.

65. Hügler M, Wirsen CO, Fuchs G, Taylor CD, Sievert SM. Evidence for autotrophic $\mathrm{CO}_{2}$ fixation via the reductive tricarboxylic acid cycle by members of the $\varepsilon$ subdivision of Proteobacteria. J Bacteriol. 2005;187(9):3020-7.

66. Hoefman S, van der Ha D, Boon N, Vandamme P, De Vos P, Heylen K. Niche differentiation in nitrogen metabolism among methanotrophs within an operational taxonomic unit. BMC Microbiol. 2014;14:83.

67. Berg |A. Ecological aspects of the distribution of different autotrophic $\mathrm{CO}_{2}$ fixation pathways. Appl Environ Microbiol. 2011;77(6):1925-36.

68. Oostergetel GT, van Amerongen H, Boekema EJ. The chlorosome: a prototype for efficient light harvesting in photosynthesis. Photosynth Res. 2010;104(2-3):245-55.

69. Khadka B, Adeolu M, Blankenship RE, Gupta RS. Novel insights into the origin and diversification of photosynthesis based on analyses of conserved indels in the core reaction center proteins. Photosynth Res. 2017;131(2):15971.

70. Gupta RS, Khadka B. Evidence for the presence of key chlorophyllbiosynthesis-related proteins in the genus Rubrobacter (phylum Actinobacteria) and its implications for the evolution and origin of photosynthesis. Photosynth Res. 2016;127(2):201-18.

71. Geisseler D, Horwath WR, Joergensen RG, Ludwig B. Pathways of nitrogen utilization by soil microorganisms - a review. Soil Biol Biochem. 2010;42(12): 2058-67.

72. Zhang X, Niu J, Liang Y, Liu X, Yin H. Metagenome-scale analysis yields insights into the structure and function of microbial communities in a copper bioleaching heap. BMC Genet. 2016;17:21.

73. Hoffman BM, Lukoyanov D, Yang Z-Y, Dean DR, Seefeldt LC. Mechanism of nitrogen fixation by nitrogenase: the next stage. Chem Rev. 2014;114(8): 4041-62.

74. Desai MS, Assig K, Dattagupta S. Nitrogen fixation in distinct microbial niches within a chemoautotrophy-driven cave ecosystem. ISME J. 2013;7(12): 2411-23.

75. Muyzer G, Stams AJM. The ecology and biotechnology of sulphate-reducing bacteria. Nat Rev Microbiol. 2008;6:441-54.

76. Hofer U. Environmental microbiology: new diversity in the sulfur cycle. Nat Rev Microbiol. 2018;16:260-1.

77. Weckopp SC, Kopriva S. Are changes in sulfate assimilation pathway needed for evolution of C4 photosynthesis? Front Plant Sci. 2015;5:773.

78. Koprivova A, Melzer M, von Ballmoos P, Mandel T, Brunold C, Kopriva S. Assimilatory sulfate reduction in $\mathrm{C}_{3}, \mathrm{C}_{3}-\mathrm{C}_{4}$, and $\mathrm{C}_{4}$ species of Flaveria. Plant Physiol. 2001;127(2):543-50

79. Goyal P, Basniwal RK. Environmental bioremediation: biodegradation of xenobiotic compounds. In: Hashmi MZ, Kumar V, Varma A, editors. Xenobiotics in the soil environment: monitoring, toxicity and management. Cham: Springer International Publishing; 2017. p. 347-71.

80. Sarwar SK, Gupta R. Biodegradation of xenobiotic compounds: an overview. In: Bhakta JN, editor. Handbook of research on inventive bioremediation techniques. Hershey: IGI Global; 2017. p. 186-212.

81. Gouma S, Fragoeiro S, Bastos AC, Magan N. Bacterial and fungal bioremediation strategies. In: Surajit D, editor. Microbial biodegradation and bioremediation. Oxford: Elsevier; 2014. p. 301-23.

82. Peng $\mathrm{RH}$, Xiong AS, Xue Y, Fu XY, Gao F, Zhao W, Tian YS, Yao QH. Microbial biodegradation of polyaromatic hydrocarbons. FEMS Microbiol Rev. 2008; 32(6):927-55.

83. Jada SUU, Zada S, Khan I, Sajjad W, Rafio M, Shah AA, Hasan F. Biodegradation of polyethylene by bacterial strains isolated from Kashmir cave, Buner. Pakistan J Cave Karst Stud. 2017:79(1):73-80.

84. Faust K, Raes J. Microbial interactions: from networks to models. Nat Rev Microbiol. 2012;10(8):538-50.

85. Sengupta S, Chattopadhyay MK, Grossart H-P. The multifaceted roles of antibiotics and antibiotic resistance in nature. Front Microbiol. 2013:4:47.

86. Luncini G, Demain AL. Secondary metabolism in bacteria: antibiotic pathways, regulation, and function. In: Lengeler JW, Drews D, Schlegel HG, editors. Biology of the prokaryotes. Blackwell Science Ltd; 2009. p. 627-651.
87. Vaz Jauri P, Bakker MG, Salomon CE, Kinkel LL. Subinhibitory antibiotic concentrations mediate nutrient use and competition among soil Streptomyces. PLoS One. 2013;8(12):e81064.

88. Bhullar K, Waglechner N, Pawlowski A, Koteva K, Banks ED, Johnston MD, Barton HA, Wright GD. Antibiotic resistance is prevalent in an isolated cave microbiome. PLoS One. 2012;7(4):e34953.

89. Liu Z, Wang W, Zhu Y, Gong Q, Yu W, Lu X. Antibiotics at subinhibitory concentrations improve the quorum sensing behavior of Chromobacterium violaceum. FEMS Microbiol Lett. 2013;341(1):37-44.

90. Moloney MG. Natural products as a source for novel antibiotics. Trends Pharmacol Sci. 2016:37(8):689-701.

91. Cheeptham N. Cave microbiomes: a novel resource for drug discovery, vol. 1: Springer Science \& Business Media; 2012

92. Axenov-Gibanov DV, Voytsekhovskaya IV, Tokovenko BT, Protasov ES, Gamaiunov SV, Rebets YV, Luzhetskyy AN, Timofeyev MA. Actinobacteria isolated from an underground lake and moonmilk speleothem from the biggest conglomeratic karstic cave in Siberia as sources of novel biologically active compounds. PLoS One. 2016;11(2):e0149216.

93. Ghosh S, Kuisiene N, Cheeptham N. The cave microbiome as a source for drug discovery: reality or pipe dream? Biochem Pharmacol. 2017;134:18-34.

\section{Publisher's Note}

Springer Nature remains neutral with regard to jurisdictional claims in published maps and institutional affiliations.

\section{Ready to submit your research? Choose BMC and benefit from:}

- fast, convenient online submission

- thorough peer review by experienced researchers in your field

- rapid publication on acceptance

- support for research data, including large and complex data types

- gold Open Access which fosters wider collaboration and increased citations

- maximum visibility for your research: over $100 \mathrm{M}$ website views per year

At $\mathrm{BMC}$, research is always in progress.

Learn more biomedcentral.com/submissions 